\title{
Good in The Worst: COVID-19 Restrictions and Ease in Global Air Pollution
}

\author{
Naser A. Anjum \\ Department of Botany, Aligarh Muslim University, Aligarh - 202002 U.P. (India) \\ E-mail:dnaanjum@gmail.com; anjum@ua.pt
}

SCOPUS author ID: https://www.scopus.com/authid/detail.uri?authorId=23097123400 


\begin{abstract}
Severe acute respiratory syndrome coronavirus 2 (SARS-CoV-2), known to cause 2019coronavirus disease (COVID-19) pandemic is a zoonotic coronavirus and crosses species to infect human populations, where an efficient transmission of virus occurs human-tohuman. Nationwide lockdown is being adopted to stop public transport, keep people at their homes and out of their work, and maintain social distancing. In turn, large geographic areas in the world (including China, Italy, Spain, and USA) has been almost halted. This temporary halt is significantly slashing down the air pollution (air pollutants and warming gases) in most cities across the world. This paper: (i) introduces both COVID-19 and air pollution; (ii) overviews the relation of air pollution with respiratory/lung diseases; (iii) compiles and highlights major data appeared in media and journals reporting lowering of air pollution in major cities those have been highly impacted by the COVID-19; and also (iv) lists the way forward in the present context. Because COVID-19 is an ongoing pandemic and currently far from over, strong conclusions could not be drawn with very limited data at present. The temporary slashed down global air pollution as a result of COVID-19 restrictions are expected to stimulate the researchers, policy makers and governments for the judicious use of resources; thereby minimise the global emissions, and maintain their economies once the pandemic eases. On the other, lifting of the nationwide lockdown and eventual normalisation of the temporarily halted sectors may also reverse the currently COVID-19 pandemic-led significantly slashed down global air pollution that could make the future respiratory health crisis grimmer.
\end{abstract}

Keywords Coronavirus; SARS-CoV-2; COVID-19; respiratory diseases; air pollution 


\section{Introduction}

The recent global outbreak of an infectious coronavirus disease (COVID-19) has already been considered as a global health emergency by the world health organization (WHO). Previously known by the provisional name 2019-novel coronavirus (2019-nCoV), severe acute respiratory syndrome coronavirus 2 (SARS-CoV-2), a strain of coronavirus is known to cause COVID-19 (Chen and Li 2020; El-Feky et al. 2020). SARS-CoV-2 is a zoonotic coronavirus that has crossed species to infect human populations, where an efficient transmission of virus occurs human-to-human. SARS-CoV-2 has already spread over about 200 countries in the world and, as of $4^{\text {th }}$ April, the WHO has reported 1,051, 635 confirmed cases and 56,985 confirmed deaths in total due to COVID-19 (WHO 2020) (Table 1; Fig. 1). Therefore, the world is trying every approach to control the rapid transmission of SAAR-CoV-2 and so the spread of COVID-19 in humans. In an effort to slow the virus' very fast pace spread, a large number of countries is adopting the strategy of practicing social distancing and telling people to stay in their homes through implementing the strict lockdown. Worldwide, the streets of the most cities are deserted; the normally bustling pubs, bars and theatres have been closed; operation of the public transport has been resricted; the most extensive travel restrictions are in place, and people are working remotely from their homes. Since mid-February 2020 and/or beginning of March 2020, about three-week nationwide lockdown has halted increasingly large geographic areas which is impacting economies across the world and also the staus of global air pollution.

Table 1. COVID-2019 confirmed cases and deaths as of $4^{\text {th }}$ April 2020 (WHO 2020).

\begin{tabular}{lll}
\hline Region & $\begin{array}{l}\text { Confirmed cases of } \\
\text { COVID-2019 }\end{array}$ & Confirmed death \\
\hline Global & 1051635 & 56985 \\
European Region & 583141 & 42334 \\
Western Pacific Region & 110362 & 3809 \\
Eastern Mediterranean Region & 65903 & 3592 \\
Region of the Americas & 279543 & 6802 \\
South-East Asia Region & 6528 & 267 \\
African Region & 5446 & 170 \\
\hline
\end{tabular}




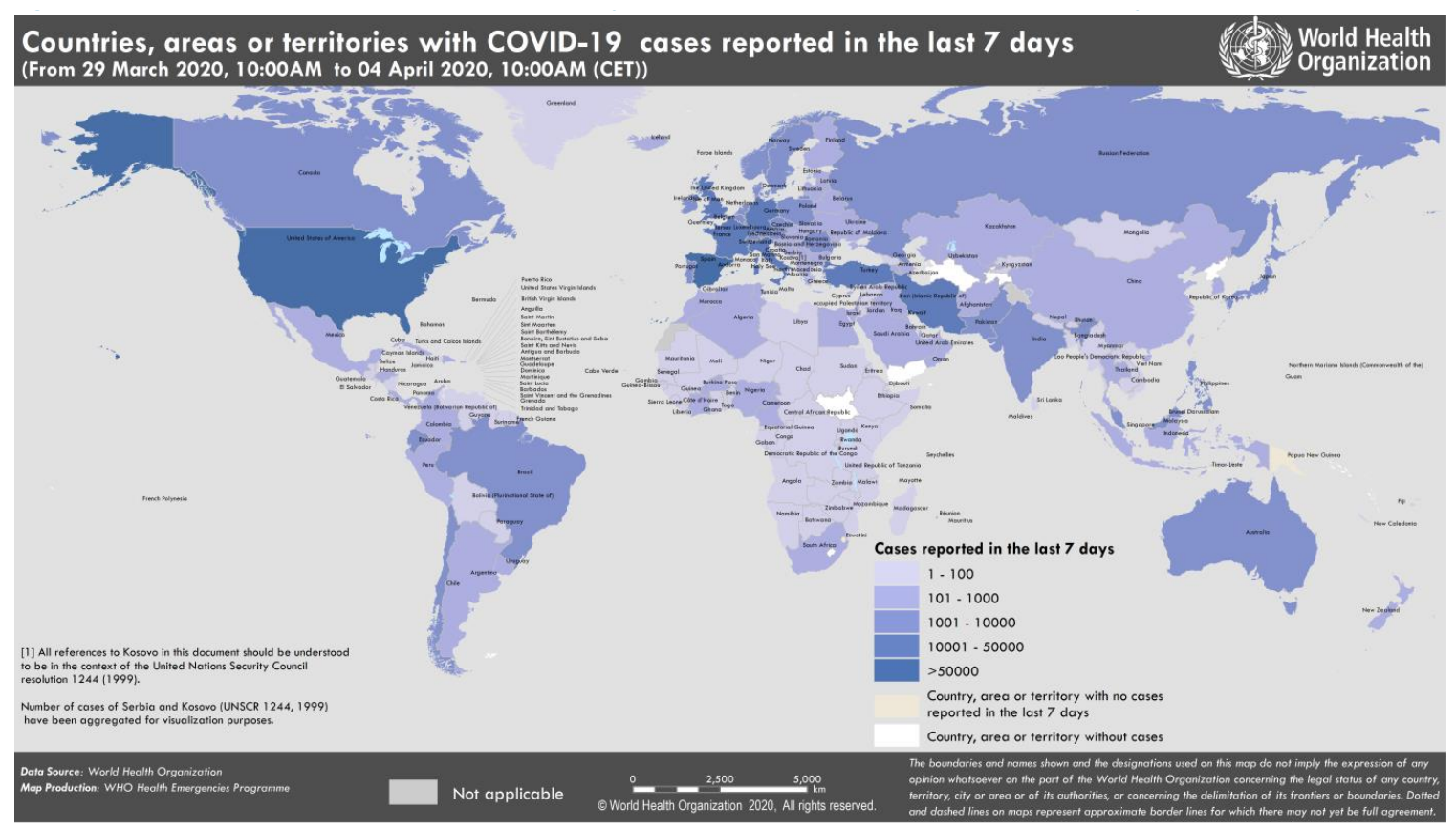

Fig. 1. Countries, territories or areas with confirmed reported cases of COVID-19 as of the $30^{\text {th }}$ of March 2020 (WHO 2020).

In the following sections, air pollution is introduced; the relation of air pollution with major respiratory/lung diseases is overviewed; major data appeared in media and journals reporting lowering of air pollution in major cities those have been highly impacted by the COVID-19 are compiled and highlighted; and also the future prospects in the present context are enlightned.

\section{Air pollution}

Owing its importance as a major part of several essential cycles on Earth, air is required to survive by most species including human beings. Air provides oxygen $\left(\mathrm{O}_{2}\right)$ for respiration to occur, and also carbon dioxide $\left(\mathrm{CO}_{2}\right)$ for photosynthesis to happen in plants. However, rapid establishment of industries aimed at making our daily life confartable, on the other hand, is adding highly toxic substances to air and making it very hard to breath. Air is called polluted when it exhibits harmful concentrations of a mix of particles and gases such as black carbon (soot), smoke, mold, pollen, methane $\left(\mathrm{CH}_{4}\right)$, and $\mathrm{CO}_{2}$. Particulate matter (PM), black carbon, ground-level ozone $\left(\mathrm{O}_{3}\right)$, nitrogen dioxide $\left(\mathrm{NO}_{2}\right)$, nitrous oxide $\left(\mathrm{N}_{2} \mathrm{O}\right)$, sulfur dioxide $\left(\mathrm{SO}_{2}\right)$ and carbon monoxide $(\mathrm{CO})$ are among the major types of air pollutants (Fig. 2). Increasing levels of small size components or 
PM (PM10; PM2.5; UFP-ultrafine particles, $<0.1 \mathrm{~mm}$ in diameter, 20-times smaller than the width of a human hair) have been confirmed in air sampled in the major world cities. PMs are contributed mostly as by-products of combustion from coal-fired power stations, wood and charcoal-burning stoves, vehicle engines and factories. In particular, PM10 $(<10$ micrometers) and PM2.5 ( $<2.5$ micrometers) can be breathed deeply into the lungs and may cross into the bloodstream; therefore, pose higher health risks (Nunez 2019).

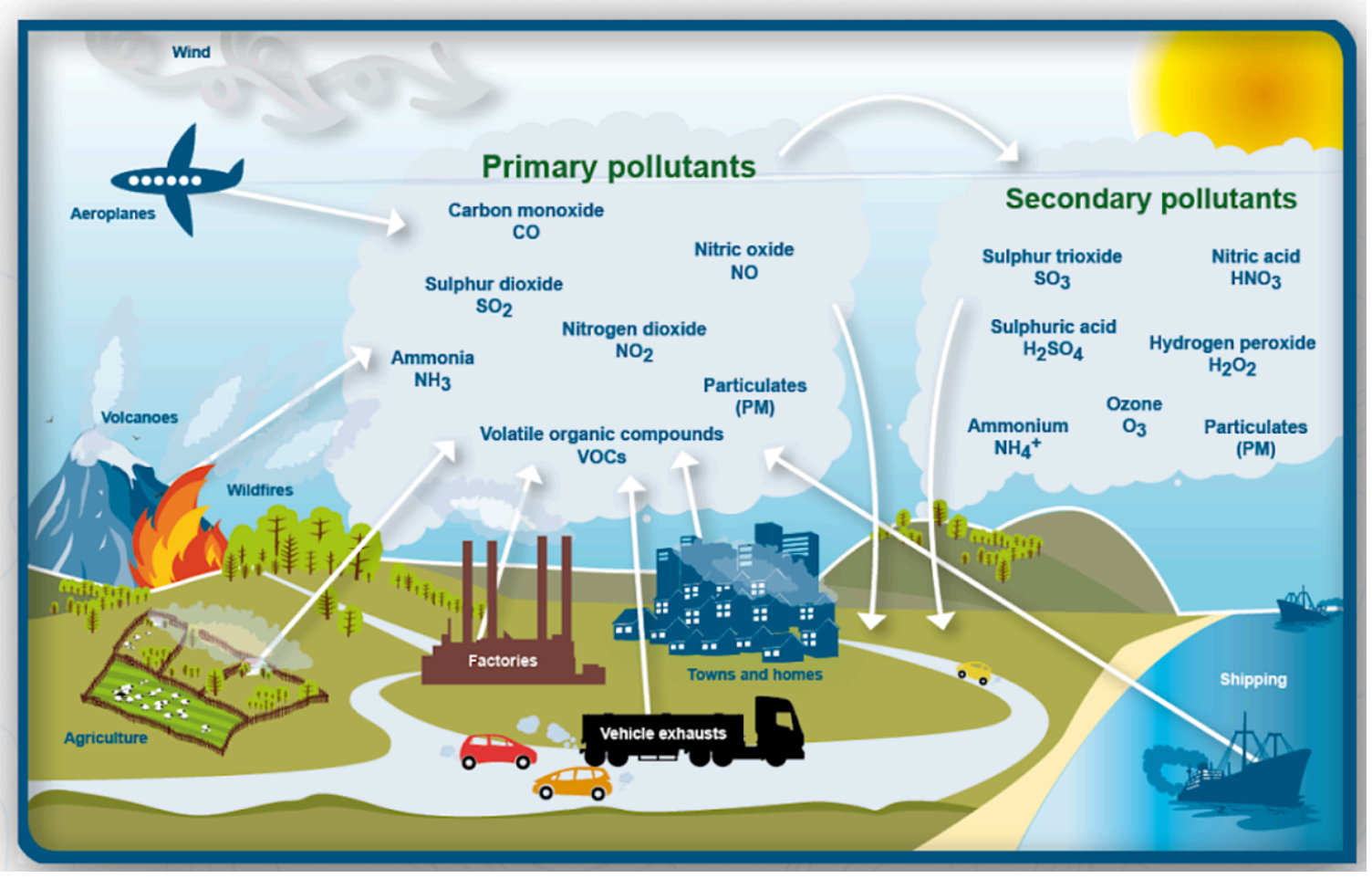

Fig. 2. Types and sources of major air pollutants (Helen 2020).

\subsection{Air pollution and respiratory/lung diseases}

Air pollution is known since long back to affect all regions of the world. Notably, in addition to smog, soot, greenhouse gases $\left.\left(\mathrm{CO}_{2} ; \mathrm{CH}_{4}\right), \mathrm{N}_{2} \mathrm{O} ; \mathrm{O}_{3}\right)$, varyingly affect the planet and our health. Both indoor and ambient air pollution exposure have been argued as a major risk to respiratory health worldwide, particularly in low- and middle-income countries (Saleh et al. 2020). $\mathrm{NO}_{2}$ at concentrations above 200 micrograms per cubic metre has beeb considered as a toxic gas which causes significant inflammation of the airways (WHO 2018a). Major health consequences of air pollutants include respiratory infections, asthma, chronic obstructive pulmonary disease, lung cancer, even in 
combination with stroke and heart diseases (Kim et al. 2018). Globally, 9\% of deaths are contributed by air pollution, and this varies from $2 \%$ to $15 \%$ by country. During 2017 , air pollution contributed to $9 \%$ of deaths globally. Give this, air pollution has been considered as one of the world's leading risk factors for death (Ritchie and Roser 2020) (Figs. 3 and 4). Nine out of ten people have to breath in air containing high levels of pollutants. Such data is making the impact of air pollution on human health grimmer (WHO 2018b). Compared to high-income countries, 49\% cities and most of the cities $(97 \%)$ in low- and middle- income countries with $>100,000$ inhabitants were reported to not meeting the WHO air quality guidelines in the year 2018 (WHO 2018c). Though WHO is continiously working with countries to monitor air pollution and improve air quality, air pollution has been reported to cause 7 million deaths worldwide each year, mostly through noncommunicable diseases including acute respiratory infections like pneumonia (Healio 2018). Earlier, notable health risks of air pollution and also the historical highlights of its toxicology has also been very well-discussed in literature (Stanek et al. 2011; Kurt et al. 2016; Soriano et al. 2017; Costa 2018; Glencross et al. 2020).

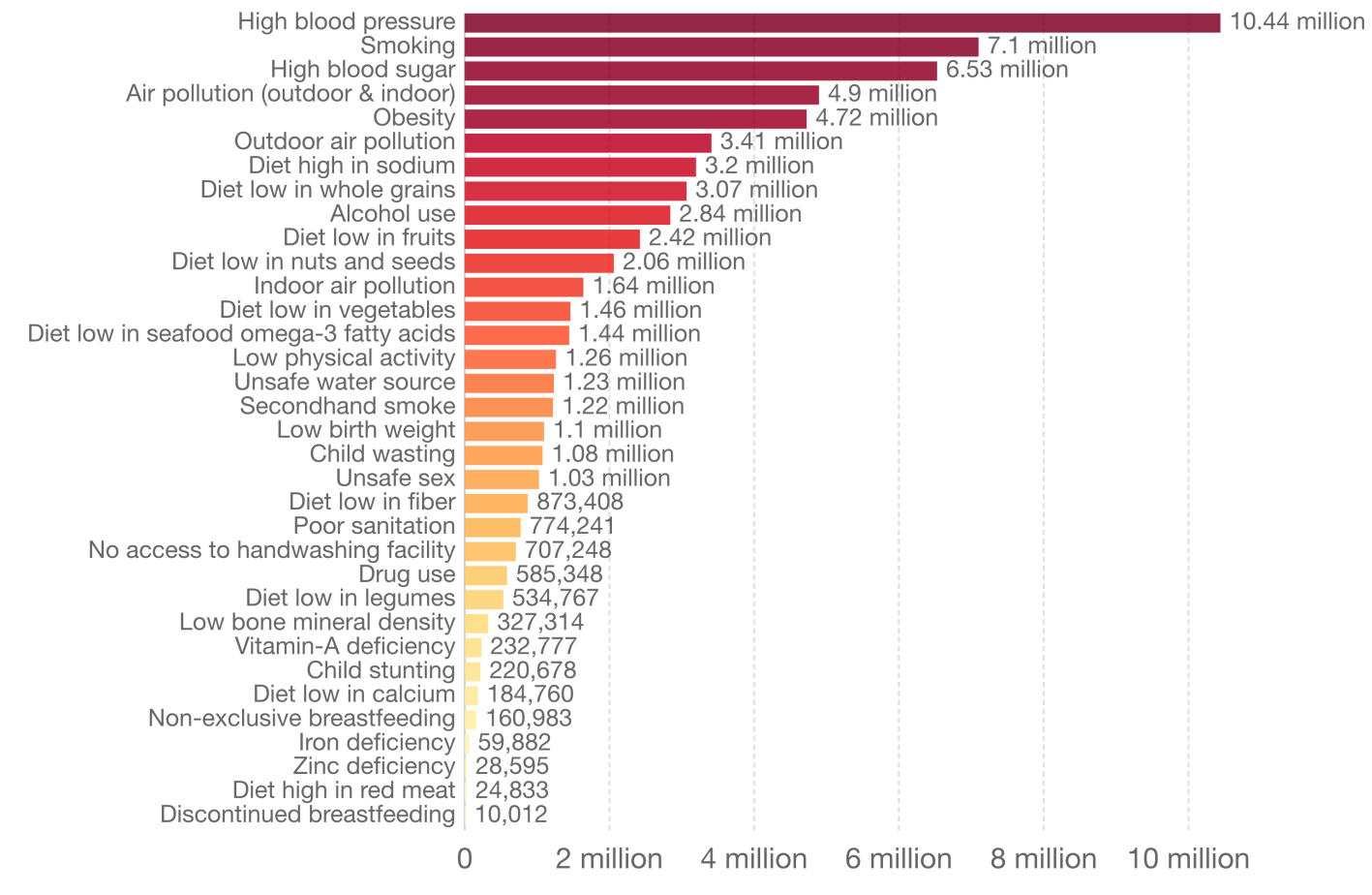

Source: IHME, Global Burden of Disease (GBD)

Fig. 3. Data exhibiting diease burden by risk factor in the year 2017. (Ritchie and Roser 2020). 


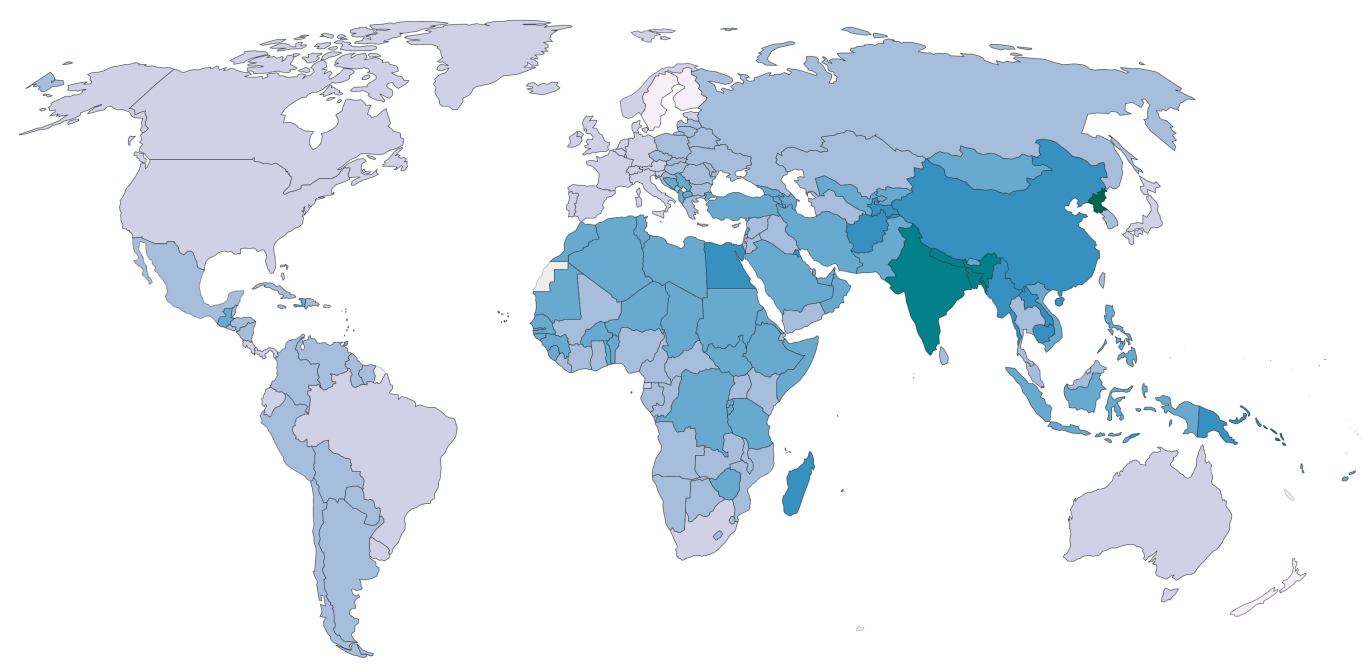

No data $0 \%$ $2.5 \% \quad 5 \%$

$7.5 \%$

$10 \%$

$12.5 \%$

$15 \%$

$17.5 \%$

Source: IHME, Global Burden of Disease

OurWorldlnData.org/air-pollution • CC BY

Fig. 4. World map highlighting share of deaths from air pollution in the year 2017 (Ritchie and Roser 2020).

\section{COVID-19 and the status of global air pollution}

In the present condition of COVID-19, experts have argued that high air pollution and smoking make people more vulnerable to this disease (Korber 2020; Perappadan 2020; TWC India Edit Team 2020). Morevoer, air pollution has been expected as a common denominator for countries with major cases of severe COVID-19 infection, China, South Korea, Iran, and northern Italy (BMJ 2020a). In particular, cities with higher air pollution were arugued as at more risk of COVID-19 (Basu 2020; Barbiroglio 2020; Korber 2020). Earlier, varying extents of air pollution have been associated with increased occurrence of respiratory tract infections and pulmonary diseases (Schikowski et al. 2005; Ciencewicki and Jaspers 2007; Neupane et al. 2010; Cohen et al. 2017; Horne et al. 2018; Liu et al. 2019; BMJ 2020b). Conditions caused by dirty air may be likely to cut survival chances under COVID-19 (European Public Health Alliance 2020).

Despite the most stringent World Health Organization guidelines and EU standards for air pollution, the levels of air pollutants still high in most cities. In particular, PM2.5 alone has been reported to caused about 412,000 premature deaths in 41 European 
countries in 2016. About 374,000 of those deaths occurred in the European Union (EU) (European Environment Agency 2019a). Therefore, air pollution has become one of the biggest environmental health risks in Europe (European Environment Agency 2019b). The Northern Italy, center of Europe's COVID-19 pandemic occurred, has the hotspot of the air pollution. In Italy, the highest daily jump was recorded in COVID-19 deaths, where as of $29^{\text {th }}$ March 2020, more than 10,000 people have died since the start of this pandemic (Spary et al. 2020). After Italy, the world's second-highest coronavirus death toll was recorded in Spain, where deadly COVID-19 has so far claimed 5,690 lives (Regencia and Alsaafin 2020). As of $29^{\text {th }}$ March 2020, the US had the most confirmed cases worldwide, surpassed China and Italy. COVID-19 cuased death in US soared to 2,100 .

Interestingly, halting of large geographic areas due to lockdown has also led to some unexpected consequences in terms of moderate to significant lowering of air pollution in most parts of the world including China, Italy, and California (Calma 2020a,b). In addition to pollution, greenhouse gas emissions have also fallen across continents (Henriques 2020). In context with the greenhouse gas emissions, $72 \%$ and $11 \%$ of the transport sector's greenhouse gas emissions are contributed by the driving and aviation respectively (IPCC 2018).

In China, the measures to minimize the spread of SARS-CoV-2 have resulted in reductions of $15 \%$ to $40 \%$ in output across key industrial sectors and also has temporarily reduced China's $\mathrm{CO}_{2}$ emissions by a quarter (Table 2).

Table 2. Status of decreases in energy demand and emissions in major sectors related with electricity demand and industrial output in China In the four-week period commencing 3 February 2020 (Myllyvirta 2020).

\begin{tabular}{ll}
\hline Sector & Status of decreases $(\%)$ \\
\hline Coal consumption at power plants & 35 \\
Operating rates for main steel products & 15 \\
Coal throughput at the largest coal port & 29 \\
Coking plant utilization & 23 \\
Satellite-based $\mathrm{NO}_{2}$ levels & 37 \\
Utilization of oil refining capacity & 34 \\
\hline
\end{tabular}


In particular with $\mathrm{CO}_{2}$, around $800 \mathrm{~m}$ tonnes of $\mathrm{CO}_{2}\left(\mathrm{MtCO}_{2}\right)$ were released in China over the same period in 2019. On the other, $\mathrm{NO}_{2}$, an air pollutant closely associated with fossil-fuel burning exhibited 36\% lower over China (in the week after the 2020 Chinese new year holiday) than in the same period in 2019 (Myllyvirta 2020; NASA 2020) (Fig. $5)$.

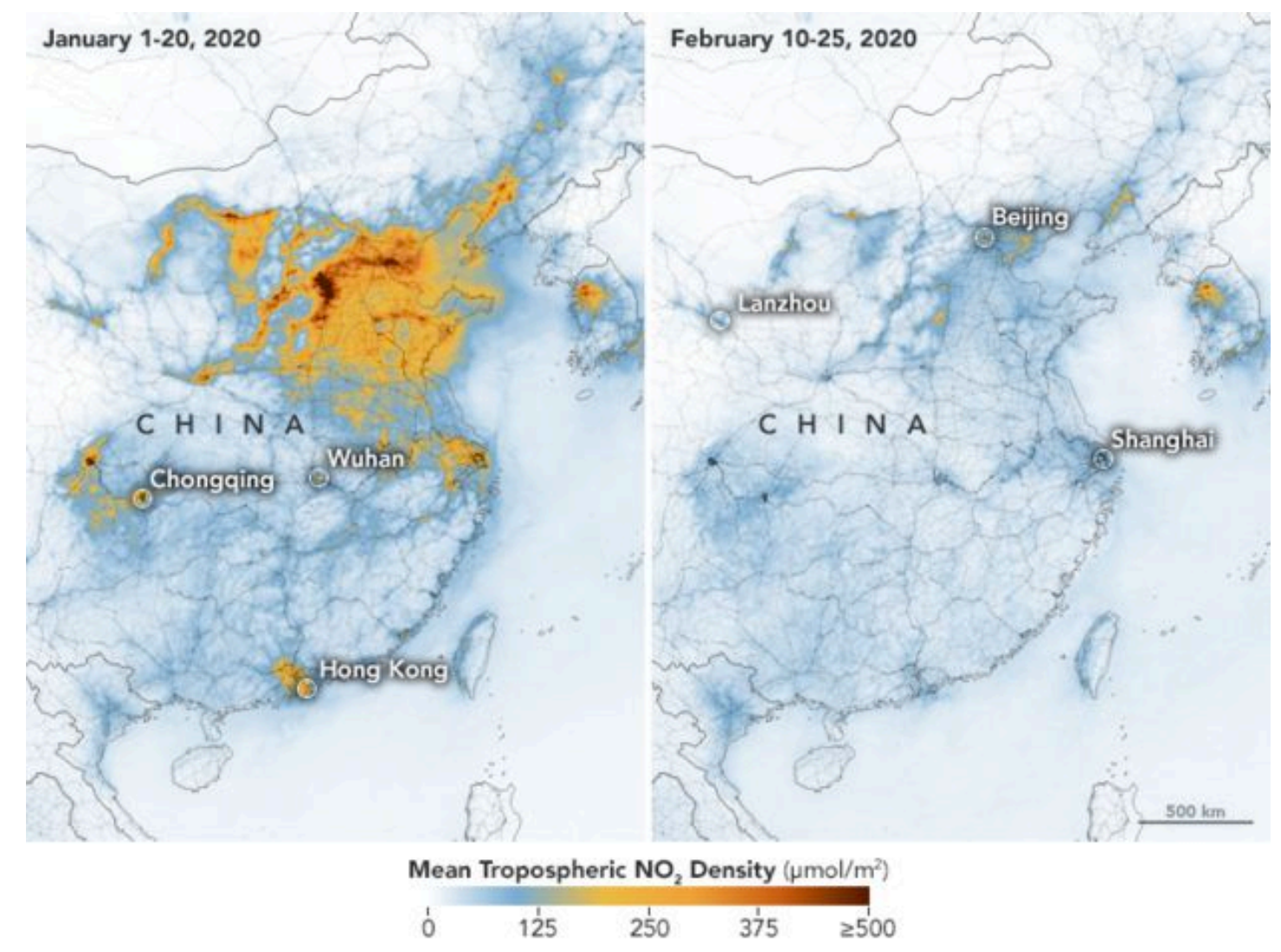

Fig. 5. Images showing the status of $\mathrm{NO}_{2}$ in major cities of China during January 1-20, 2020 and February 10-25, 2020 amid COVID-19 restrictions (image credit: McGrath 2020).

Notably, in Italy, a remarkable drop has been revealed in $\mathrm{NO}_{2}$ pollution that comes mainly from traffic, especially diesel vehicles, which are also a major source of PM (European Public Health Alliance 2020) (Fig. 6A). PM10 levels in Lombardy have fallen dramatically after 10 days of COVID-19 social distancing measures (Fig. 6B). France also showed the measured drop in NOx as economic activity and transportation therein are at a bare minimum due to COVID-19 (Balken Green Energy News 2020) (Fig. 7). 

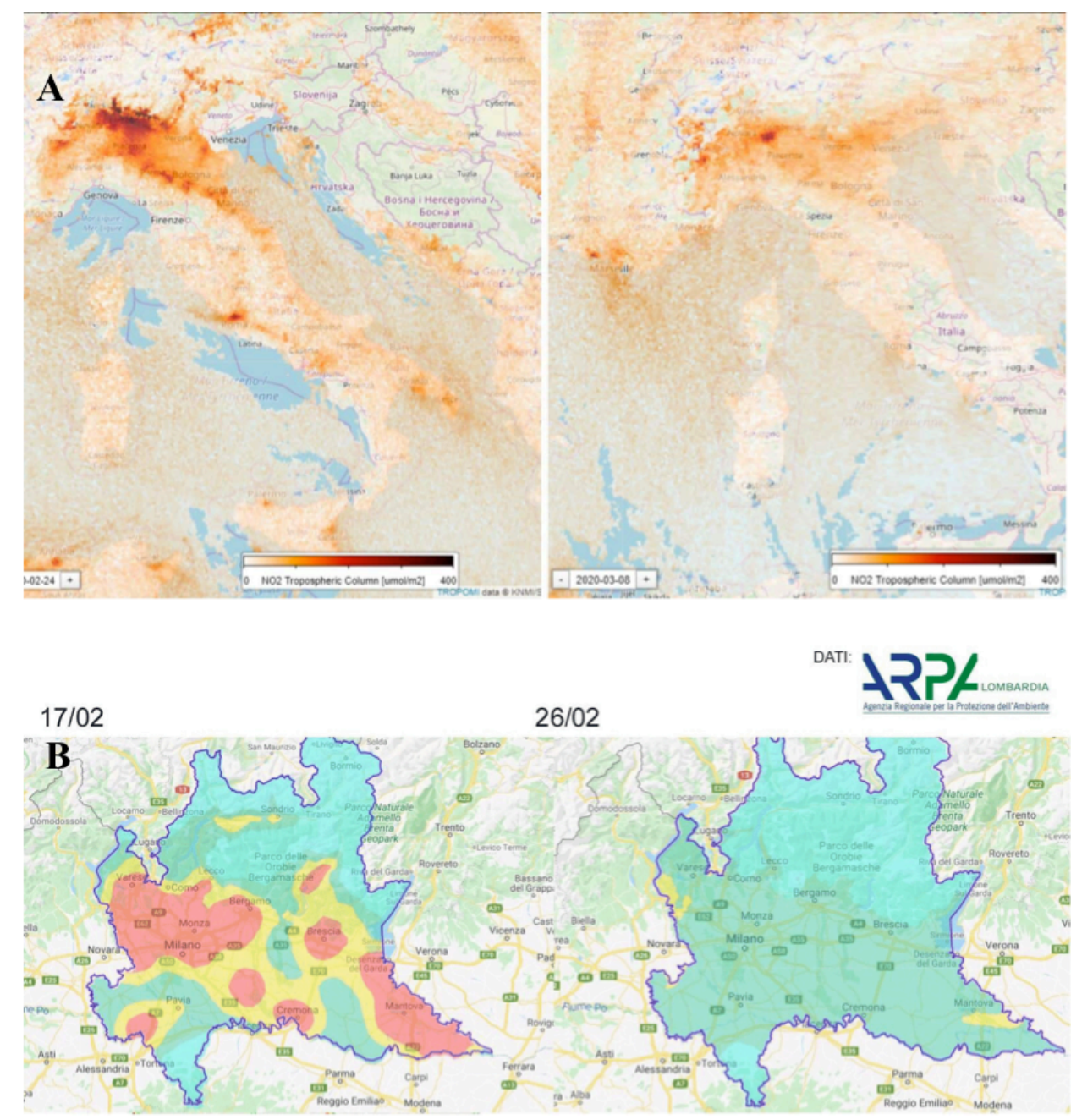

Fig. 6. Images showing the reduction in the levels of particulate matter of size 10 micrometer (PM10) in Lombardy (A) and $\mathrm{NO}_{2}$ in major cities of Italy after 10 days of COVID-19 social distancing measures (image credit: European Public Health Alliance 2020).

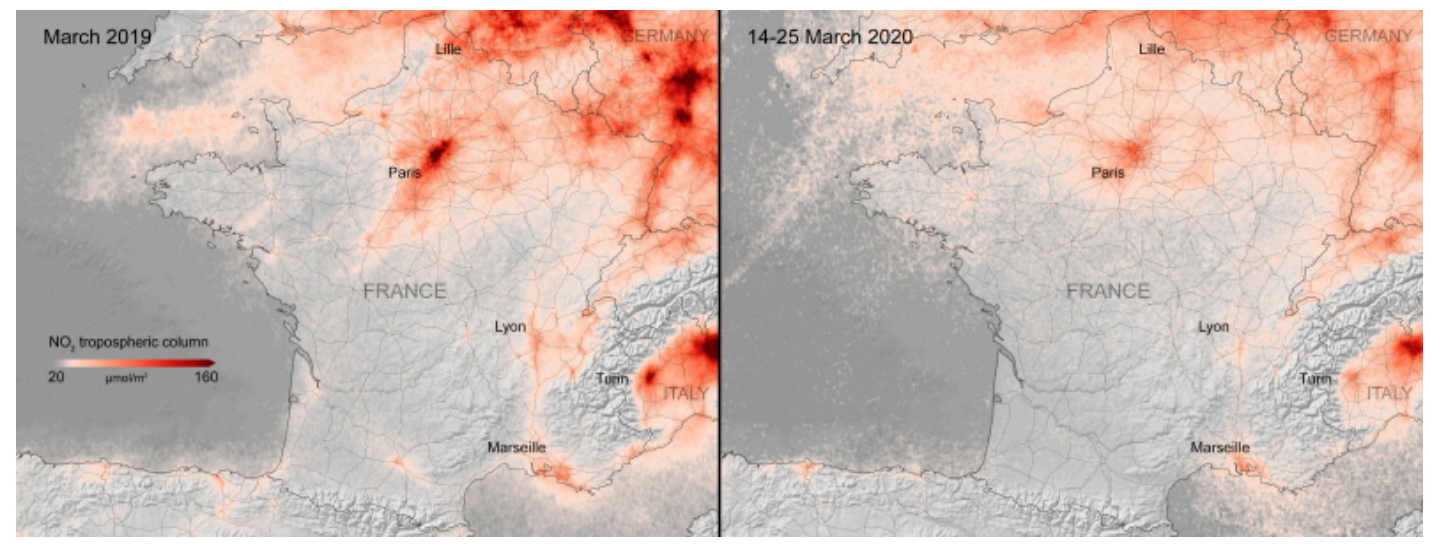

Fig. 7. Images showing the reduction in the level of $\mathrm{NO}_{2}$ in major cities of France on COVID-19 lockdowns (image credit: Balkan Green Energy News 2020). 
In the United States, the Centers for Disease Control and Prevention (CDC) had issued travel advisory for 3 states including New York, New Jersey and Connecticut to avoid non-essential travel for two weeks in an attempt to tamp down spread of coronavirus in the region. New York remains the epicenter of the COVID-19 outbreak in the US (CBS News 2020). Earlier, New York air monitoring work had revealed exceptionally high CO numbers in New York for the last year and a half (Pascus 2020). However, during the spread of COVID-19 pandemic in New York, traffic levels were estimated to be down $35 \%$ compared with a year ago. Significant decreases in the emmission of $\mathrm{CO}$ and that of the planet-heating gas $\mathrm{CO}_{2}$ have also fallen sharply. New York had also exhibited 5-10\% drop in $\mathrm{CO}_{2}$ and a solid drop in methane as well (McGrath 2020). Additionlly, COVID19 pandemic led less commercial activity and traffic dropped $\mathrm{NO}_{2}$ levels in certain areas across the United States (Fox2Detroit 2020) (Fig. 8).

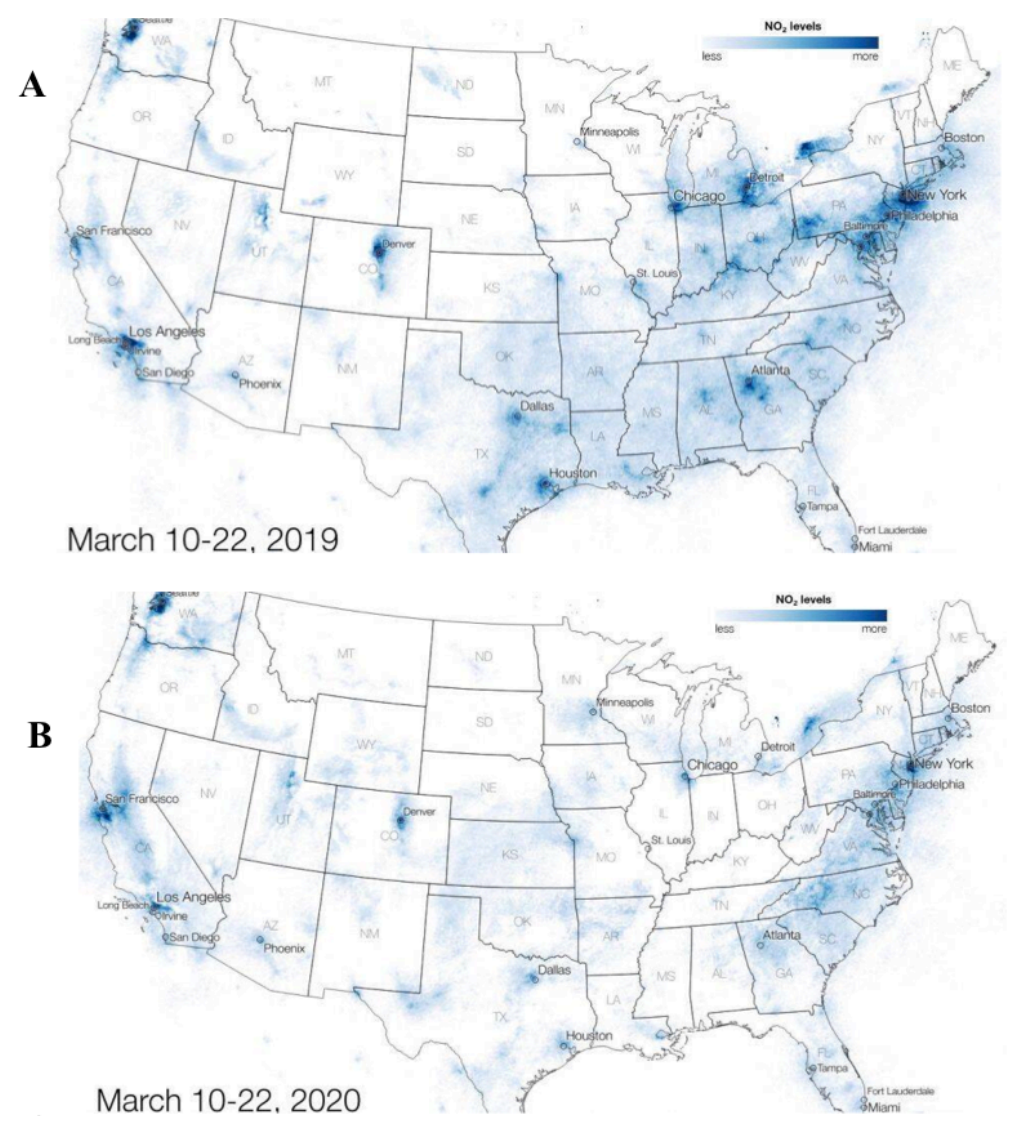

Fig. 8. Images showing the status of $\mathrm{NO}_{2}$ in major cities of United States during March 122, 2019 and March 10-22, 2020 amid COVID-19 restrictions (image credit: Fox 2 Detroit 2020). 
In context with India, air pollution has been reported to plummet in the end of second week of COVID-19 lockdown. In terms of air quality index (AQI; range: 0 to 500; good: 0-50; satisfactory: 51-100; poor: 201-300), a total of 91 cities were under 'Good' \& 'Satisfactory' category, with 31 cities with 'Good' AQI values; and no city was under 'Poor' AQI category, as on March 29, 2020 (SAFAR-India 2020; Vishnoi 2020) (Fig. 9). Additionally, the measures against COVID-19 have led to a drop in PM2.5 30\% in Delhi and by $15 \%$ in Ahmedabad and Pune, respectively (The Hindu 2020). In New Delhi, the diversion and/or ceasation of flights witnessed dropping down of the air pollution levels by $71 \%$ in just one week, where the level of PM2.5 dropped from from 91 micrograms per cubic meter (on 20 March 2020) to 26 micrograms per cubic meter in just a couple days of the lockdown (Davidson 2020). Earlier, the 'Janata Curfew', observed on March 22 (from 7 am-9 pm) led to a significant reduction in particulate matter (PM10) and nitrogen oxide (NOx), where a 44 percent reduction in PM10 levels particulalrly in Delhi between 22 and 23 March 2020 (FP 2020).

\section{Air Quality Across SAFAR Cities: AQ-Index}

27.3.2020 8:52:42 AM

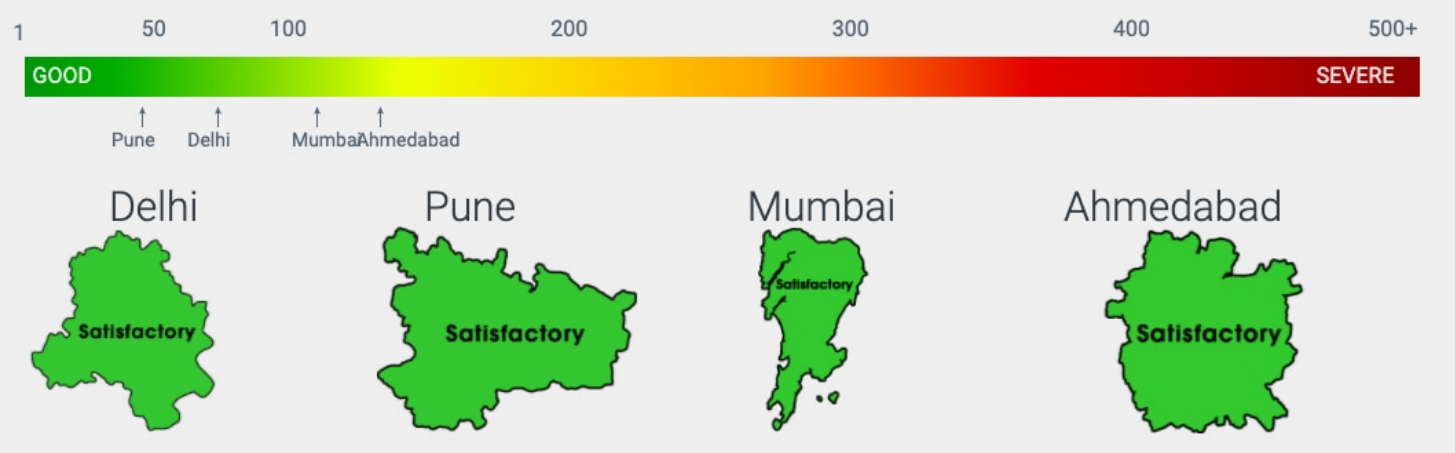

Fig. 9. Image showing air quality across major cities in India as on $27^{\text {th }}$ March 2020 (SAFAR-India 2020).

\section{Conclusions and prospects}

Because COVID-19 is an ongoing pandemic and currently far from over, strong conclusions could not be drawn with very limited data at present. No doubt air pollution is increasing worldwide and has been widely reported to be closely related with the severe lung/respiratory diseases in human. The nationwide halting of public transports and closure of major industrial units has resulted in obvious significant reductions in 
emissions of a variety of gases related to energy and transport. Indeed, industrial developments and production are necessary for supporting the world population. However, lifting of the nationwide lockdown and eventual normalization of the temporarily halted sectors may also reverse the currently COVID-19 pandemic-led slashed down global air pollution and can make the future respiratory health crisis grimmer. Hence, the indication of slowing down of public and personal trasport, and travel in slashing down the air pollution is expected to stimulate the researchers, policy makers and governments to judicious use of resources and thereby minimize the global emissions and maintain their economies once the pandemic eases.

\section{References}

Balkan Green Energy News (2020) Air pollution sharply falls worldwide on COVID-19 lockdowns, https://balkangreenenergynews.com/air-pollution-sharply-falls-worldwide-on-covid-19lockdowns/, accessed on 30 March 2020

Barbiroglio E (2020) People Living In Polluted Cities May Be At Higher Risk From COVID-19. 20 March 2020, https://www.forbes.com/sites/emanuelabarbiroglio/2020/03/20/people-living-in-pollutedcities-are-at-higher-risk-from-covid-19/\#4814581a4b99, accessed on 29 March 2020.

Basu J (2020) COVID-19 outbreak: Cities with higher air pollution at more risk, say experts. Down to Earth https://www.downtoearth.org.in/news/health/covid-19-outbreak-cities-with-higher-airpollution-at-more-risk-say-experts-70016, accessed on 28 March 2020.

BMJ (2020a) Covid-19: a puzzle with many missing pieces. 19 February 2020, doi: https://doi.org/10.1136/bmj.m627, accessed on 29 March 2020.

BMJ (2020b) https://www.bmj.com/content/368/bmj.m627/rr-3, accessed on 29 March 2020.

Calma J (2020a) Maps show drastic drop in China's air pollution after coronavirus quarantine. The Verge https://www.theverge.com/2020/3/2/21161324/coronavirus-quarantine-china-maps-air-pollution, accessed on 28 March 2020.

Calma J (2020b) Air pollution could make the COVID-19 pandemic worse for some people. The Verge https://www.theverge.com/2020/3/19/21186653/coronavirus-covid-19-air-pollution-vulnerablelung-disease-pandemic, accessed on 28 March 2020.

CBS News (2020) Coronavirus updates: U.S. deaths top 2,100 as CDC issues travel advisory for 3 states. 30 March 2020, https://www.cbsnews.com/live-updates/coronavirus-disease-covid-19-latestnews-2020-03-29/, accessed on 30 March 2020.

Chen Y, Li L (2020) SARS-CoV-2: virus dynamics and host response. The Lancet Infectious Diseases doi:10.1016/S1473-3099(20)30235-8

Ciencewicki J, Jaspers I (2007) Air pollution and respiratory viral infection. Inhal Toxicol 19:1135-1146.

Cohen AJ, Brauer M, Burnett R, Anderson HR, Frostad J, Estep K et al. (2017) Estimates and 25-year trends of the global burden of disease attributable to ambient air pollution: an analysis of data from the Global Burden of Diseases Study 2015. The Lancet 389(10082):1907-1918.

Costa DL (2018) Historical highlights of air pollution toxicology. Toxicological Sciences 164 (1): 5-8.

Davidson J (2020) EcoWatch, India's Air Pollution Plummets in COVID-19 Lockdown. Apr. 02, 2020, https://www.ecowatch.com/india-air-pollution-coronavirus-2645617908.html, accessed on 5 April 2020

El-Feky M, Bell DJ et al. (2020) COVID-19. Radiopaedia. https://radiopaedia.org/articles/covid-193?lang=us, accessed on 28 March 2020

European Environment Agency (2019a) Cutting air pollution in Europe would prevent early deaths, improve productivity and curb climate change. https://www.eea.europa.eu/highlights/cutting-airpollution-in-europe, accessed on 29 March 2020. 
European Environment Agency (2019b) Europe's urban air quality — re-assessing implementation challenges in cities. EEA Report No 24/2018, doi:10.2800/214599, https://www.eea.europa.eu/publications/europes-urban-air-quality, accessed on 29 March 2020.

European Public Health Alliance (2020) Coronavirus threat greater for polluted cities. Mar 16, 2020, https://epha.org/coronavirus-threat-greater-for-polluted-cities/, accessed on 29 March 2020.

European Public Health Alliance (2020) Coronavirus threat greater for polluted cities. Mar 16, 2020, https://epha.org/coronavirus-threat-greater-for-polluted-cities/, accessed on 29 March 2020.

FP (2020) First Post. India sees improved air quality during coronavirus lockdown, says CPCB; AQI improves to 'good' in 23 cities, 'satisfactory' in 65. Apr 02, 2020, https:/www.firstpost.com/health/india-sees-improved-air-quality-during-coronavirus-lockdownsays-cpcb-aqi-improves-to-good-in-23-cities-satisfactory-in-65-8221311.html, accessed on 5 April 2020

Fox2Detroit (2020) Air pollution drops across the globe amid COVID-19 pandemic, data suggests, https:/www.fox2detroit.com/news/air-pollution-drops-across-the-globe-amid-covid-19-pandemicdata-suggests, accessed on 30 March 2020.

Glencross DA, Ho TR, Camiña N, Hawrylowicz CM, Pfeffer PE (2020) Air pollution and its effects on the immune system. Free Radical Biology and Medicine doi:10.1016/j.freeradbiomed.2020.01.179.

Healio (2018) Air pollution kills 7 million people each year, many from pneumonia. https://www.healio.com/infectious-disease/respiratory-infections/news/online/\%7Bb82c1c99182d-4e16-96c7-f2021fb10fc8\%7D/air-pollution-kills-7-million-people-each-year-many-frompneumonia, Accessed on 28 March 2020.

Helen A (2020) The Ultimate Guide to Understanding Air Quality Data in 2020. Breez Meter, 2 Jan. 2020, https://blog.breezometer.com/ultimate-guide-understanding-air-quality-data, accessed on 31 March 2020.

Henriques M (2020) Will Covid-19 have a lasting impact on the environment? 27th March 2020, https:/www.bbc.com/future/article/20200326-covid-19-the-impact-of-coronavirus-on-theenvironment, accessed on 29 March 2020.

Horne BD, Joy EA, Hofmann MG, Gesteland PH, Cannon JB, Lefler JS et al. (2018) Short-term elevation of fine particulate matter air pollution and acute lower respiratory infection. Am J Respir Crit Care Med 198:759-766.

IPCC (2018) Intergovernmental Panel on Climate Change (IPCC 2018), Summary for Policymakers. In: Global warming of $1.5^{\circ} \mathrm{C}$. An IPCC Special Report on the impacts of global warming of $1.5^{\circ} \mathrm{C}$ above pre-industrial levels and related global greenhouse gas emission pathways, in the context of strengthening the global response to the threat of climate change, sustainable development, and efforts to eradicate poverty [V. Masson-Delmotte, P. Zhai, H. O. Pörtner, D. Roberts, J. Skea, P. R. Shukla, A. Pirani, W. Moufouma-Okia, C. Péan, R. Pidcock, S. Connors, J. B. R. Matthews, Y. Chen, X. Zhou, M. I. Gomis, E. Lonnoy, T. Maycock, M. Tignor, T. Waterfield (eds.)]. World Meteorological Organization, Geneva, Switzerland, 32 pp. ISBN: 978-92-9169-151-7.

Kim D, Chen Z, Zhou LF, Huang SX (2018) Air pollutants and early origins of respiratory diseases. Chronic Dis Transl Med 4(2):75-94.

Korber R (2020) Severe Coronavirus \& Poor Air Quality Could be Linked. BreezoMeter, https://blog.breezometer.com/coronavirus-air-quality-connection, accessed on 29 March 2020.

Kurt OK, Zhang J, Pinkerton KE (2016) Pulmonary health effects of air pollution. Curr Opin Pulm Med 22(2):138-143.

Liu Y, Pan J, Zhang H, Shi C, Li G, Peng Z et al. (2019) Short-term exposure to ambient air pollution and asthma mortality. American Journal of Respiratory and Critical Care Medicine 200(1):24-32.

McGrath M (2020) Coronavirus: Air pollution and CO2 fall rapidly as virus spreads. BBC, 19 March 2020, https://www.bbc.com/news/science-environment-51944780, accessed on 29 March 2020.

Myllyvirta L (2020) Coronavirus has temporarily reduced China's $\mathrm{CO}_{2}$ emissions by a quarter. 19 Feb. 2020, Carbon Briefs, https://www.carbonbrief.org/analysis-coronavirus-has-temporarily-reducedchinas-co2-emissions-by-a-quarter, accessed on 30 March 2020.

NASA (2020) Airborne Nitrogen Dioxide Plummets Over China, https:/www.earthobservatory.nasa.gov/images/146362/airborne-nitrogen-dioxide-plummets-overchina, accessed on 30 March 2020. 
Neupane B, Jerrett M, Burnett RT, Marrie T, Arain A, Loeb M (2010) Long-term exposure to ambient air pollution and risk of hospitalization with community-acquired pneumonia in older adults. Am J Respir Crit Care Med 181:47-53.

Nunez C (2019) Climtae 101: Air Pollution. National Geographic, Feb. 4, 2019, https:/www.nationalgeographic.com/environment/global-warming/pollution/, accessed on 29 March 2020.

Pascus B (2020) City traffic levels plummet 35\% following new executive orders. 16 March 2020. https://www.crainsnewyork.com/coronavirus/city-traffic-levels-plummet-35-following-newexecutive-orders, accessed on 29 March 2020.

Perappadan BS (2020) Coronavirus: Air pollution may further impact patients, say doctors. The Hindu, New Delhi, 17 March 2020, https:/www.thehindu.com/sci-tech/health/coronavirus-air-pollutionmay-further-impact-patients-say-doctors/article31092789.ece, accessed on 29 March 2020.

Regencia T, Alsaafin L (2020) Italy's coronavirus death toll passes 10,000: Live updates. Al Jazeera, March 29 2020, https://www.aljazeera.com/news/2020/03/coronavirus-cases-top-100000-italy-deathsrise-live-updates-200327231629838.html, accessed on 29 March 2020.

Ritchie H, Roser M (2020) Air Pollution. Published online at OurWorldInData.org. retrieved from: 'https://ourworldindata.org/air-pollution', accessed on 31 March 2020.

SAFAR - India (2020) System of Air Quality and Weather Forecasting And Research. http://safar.tropmet.res.in/, accessed on 5 April 2020.

Saleh S, Shepherd W, Jewell C, Lam NL, Balmes J, Bates MN, Lai PS, Ochieng CA, Chinouya M, Mortimer K (2020) Air pollution interventions and respiratory health: a systematic review. The International Journal of Tuberculosis and Lung Disease 24 (2):150-164.

Schikowski T, Sugiri D, Ranft U, Gehring U, Heinrich J, Wichmann HE, Krämer U (2005) Long-term air pollution exposure and living close to busy roads are associated with COPD in women. Respiratory research, 6(1):152.

Soriano JB, Abajobir AA, Abate KH, Abera SF, Agrawal A, Ahmed MB et al. (2017) Global, regional, and national deaths, prevalence, disability-adjusted life years, and years lived with disability for chronic obstructive pulmonary disease and asthma, 1990-2015: a systematic analysis for the Global Burden of Disease Study 2015. The Lancet Respiratory Medicine 5(9):691-706.

Spary S, Donato VD, Braithwaite S (2020) CNN. March 27, 2020, https:/edition.cnn.com/2020/03/27/europe/101-year-old-coronavirus-scli-intl/index.html, accessed on 29 March 2020.

Stanek LW, Brown JS, Stanek J, Gift J, Costa DL (2011) Air pollution toxicology - a brief review of the role of the science in shaping the current understanding of air pollution health risks. Toxicological Sciences, 120(suppl_1), S8-S27.

The Hindu (2020) Air quality improves amid lockdown in India, 2 Apr 2020, https:/www.thehindu.com/news/national/air-quality-improves-in-india-amidlockdown/article31234638.ece, accessed on 5 April 2020.

TWC India Edit Team (2020) COVID-19: High Pollution, Smoking Make You More Vulnerable to Novel Coronavirus Disease, Warn Doctors. The Weather Channel India, 8 March 2020, https://weather.com/en-IN/india/pollution/news/2020-03-18-covid-19-pollution-smokingvulnerable-novel-coronavirus-disease, accessed on 29 March 2020.

Vishnoi A (2020) Lockdown clears up India's air, Economics Times, Apr 2, 2020, https://economictimes.indiatimes.com/news/politics-and-nation/lockdown-clears-up-indiasair/articleshow/74942627.cms, accessed on 5 April 2020.

Westcott B, Marsh J, Woodyatt A (2020) Global coronavirus pandemic kills more than 30,000, CNN, March 29, 2020, https://edition.cnn.com/world/live-news/coronavirus-outbreak-03-29-20-intlhnk/index.html, accessed on 29 March 2020.

WHO (2020) Coronavirus disease 2019 (COVID-19) Situation Report - 75. https://www.who.int/docs/default-source/coronaviruse/situation-reports/20200404-sitrep-75covid-19.pdf?sfvrsn=99251b2b_2, accessed on 5 April 2020.

WHO (2018a) Ambient (outdoor) air pollution. 2 May 2018. https://www.who.int/news-room/factsheets/detail/ambient-(outdoor)-air-quality-and-health, accessed on 30 March 2020.

WHO (2018b) 9 out of 10 people worldwide breathe polluted air, but more countries are taking action. WHO News Room, 2 May 2018, https://www.who.int/news-room/detail/02-05-2018-9-out-of-10- 
people-worldwide-breathe-polluted-air-but-more-countries-are-taking-action, accessed on 30 March 2020.

WHO (2018c) WHO global urban ambient air pollution database (update 2018). http://www.who.int/airpollution/data/cities/en/, accessed 28 March 2020. 